\title{
Effect of Liquidity Management on Performance of Commercial Banks in Kenya
}

\author{
Wilson Aggrey Ogama Kitere* $\quad$ Prof. Gregory S.Namusonge $\quad$ Dr. Elizabeth Nambuswa Makokha \\ School of Human Resource Development, Department of Entrepreneurship and Procurement, Leadership and \\ management,. Jomo Kenyatta University of Agriculture and Technology, P.O. Box 62000 - 00200, Nairobi \\ Kenya
}

\begin{abstract}
The purpose of the study was to analyze the effect of Liquidity management on performance of commercial banks in Kenya. The study was based on Portfolio theory of Cash Management, Cash Management theory, Transaction Cost theory, Free Cash Flow theory and pecking order theory. The study used mixed research design which involves collecting and analyzing both qualitative and quantitative data. The target population of the study comprised the 6913 employees in management and supervisory cadres in commercial banks in Kenya. Stratified sampling technique was used to identify the sample size in every stratum. Data collection instruments were both structured and unstructured questionnaires. Data collection methods were both primary and secondary. The data was analyzed using Statistical Program for Social Sciences (SPSS) windows version 21. Multiple linear regression analysis was carried out to analyze the determinants of cash flow management on performance of commercial banks in Nairobi City County, Kenya. Pilot test was carried out for validity and reliability of research instruments. Regression analysis was carried out to test the significant levels of one variable to the other in the study. ANOVA was carried out to test the hypotheses of the study. The study is significant to the banking sector and the government of Kenya in formulation of different financial decisions and in policy making. The results of the study indicate that all the independent variable have a significant positive effect on performance of Commercial banks Kenya. The findings revealed that commercial banks in Kenya carry out liquidity management practice and that inflation rates influence interest rates in commercial banks in Kenya. Liquidity management practice was found to be positively related to performance of commercial banks in Kenya. The study recommends that the management of commercial banks in Kenya should be enhanced through frequent audits to be able to curb interest rates especially the unanticipated inflation which adversely affects the functions of money by undermining wealth holders' confidence in its ability to be used as medium of exchange and store of value. They should also maintain the minimum liquidity requirement as stated by the Central Bank of Kenya as both illiquidity and excess liquidity are financial diseases that can easily erode the profit base of a bank as they affect bank's attempt to attain high profitability-level. They should also put into consideration liquidity levels in pursuit of high profit for it can cause great illiquidity, which reduces the customers' patronage and loyalty.
\end{abstract}

Keywords: Liquidity, Financial Performance

DOI: $10.7176 / \mathrm{EJBM} / 11-17-04$

Publication date:June $30^{\text {th }} 2019$

\subsection{Introduction}

Globally in 2008, the world economy faced its most dangerous crisis since the Great depression of the 1930s. The contagion, which began in 2007 when sky- high home prices in the United States finally turned decisively downward, spread quickly, first to the U.S. financial sector and then to financial markets overseas. The carnage was not limited to the financial sector, however, as companies that normally rely on credit suffered heavily. In December, the National Bureau of Economic Research, the private group recognized as the official arbiter of such things, determined that a recession had begun in the United States in December 2007, which made this already the third longest recession in U.S. since World War II (Havemann, 2008). (Hillier et el., 2013) explained that in recent years, many companies have found cash very difficult to come by. As most people know, many banks ran out of cash in 2008 and 2009 as bad debts, lack of short term financing, and poor profitable opportunities combined to cause the most severe crisis in the financial sector for decades. Governments stepped into the breach and used taxpayers' money to shore up their financial institutions. Canada's financial system successfully navigated the global financial crisis, and stress tests suggest that major financial institutions would continue to be resilient to credit, liquidity, and contagion risks arising from a severe scenario. The regulated and supervisory framework is strong, and is complemented by a credible federal system of safety nets, although there is no single body with an explicit mandate to take a comprehensive view of system risks or undertake crisis preparedness (IMF, 2014). U.K commercial real estate has been buoyant: annual price growth peaked in early 2015 above 10 per cent per annum. After the recession, domestic banks have reduced their commercial real estate exposures, but international investors have picked up the slack and now account for more than one half of commercial real estate financing flows IMF, (2014).

Regionally, a recent study by Global Financial Integrity (GFI) estimates illicit financial flows out of 
developing counties at 858 billion U.S. dollars to 1.06 trillion U.S. dollars per year. Amongst developing countries, Africa presents the most analytical difficulties because countries with inadequate data account for nearly 37 per cent of regional GDP. One thing is certain: while African countries have had to shoulder a heavy debt burden, a number of researchers such as (Ndikumana, 2008), have shown that sustained illicit outflows have turned the continent into a net creditor to the rest of the world (IMF,2014). Seminal research at GFI on the absorption of illicit funds show that while some of the private assets held outside their countries by developing country nationals may be legitimate, the bulk of such funds are certainly not. This is because an estimate of illicit capital outflows provided by economic models such as the world Bank residual model and the trade misinvoicing model account for the bulk of deposits reported by banks to the Bank for International Settlements and by offshore financial centers (IMF, 2014). Donnelly (2015) affirmed that financial flows from Africa are a large growing problem. Averaging $4 \%$ of gross domestic product, they are outstripping foreign direct investment and official development aid to the continent. Africa lost an annual average of 60.3 billion US dollars, or around $4 \%$ of GDP in illicit outflows between 2003 and 2012. During the same period, Official Development Aid (ODA) and Foreign Direct Investment (FDI) averaged 42.1 billion US dollars and 43.8 billion US dollars respectively. Illicit flows for SubSaharan Africa, in 2012, were estimated to be 68.6 billion dollars, just slightly less that ODA and FDI combined coming in 41.1 billion dollars and 35.1 billion dollars. Research estimates that Africa's capital stock would have increased by more than $60 \%$ if these illicit funds remained on the continent, while GDP per capita would be $15 \%$ higher.

Donnelly (2015) confirmed that these unlawful money flows involve practices such as tax evasion-through trade misinvoicing and abusive transfer pricing-money laundering, bribery by international companies and abuse of office by public officials. Referencing research done by a high level panel of the African Union and United Nations Economic Commission for Africa examining illicit financial flows, noted that large commercial corporations account for the vast majority, or $65 \%$, of illicit money flows, following by organized crime (30\%) and corrupt practices (5\%). Trade misinvoicing- or deliberate over and under invoicing of trade transactions-was the most widely documented method of transferring illegal money across borders, accounting for $67.4 \%$ of all illegal outflows between 2003 and 2012.

Nationally, Kenya's financial stability has grown in terms of its contribution to overall Domestic Product (GDP). However, there are downside risks to Kenya's macro- financial conditions. Domestically, the banking subsector faced liquidity risks coupled with skewed distribution and corporate governance issues that resulted in two banks being placed under receivership in 2015; and a third bank for the first half of 2016, for the first time in over a decade. One bank is undergoing liquidation process, while another one was re-opened. The subsector also recorded increased credit risks, with Non-Performing Loans ( NPLs) rising faster than historical trends and credit to private sector slowdown to about 14 per cent of GDP Financial Stability Report, (CBK, 2016).The year 2015 also experienced exchange rates and interest rates volatility in Q1 through Q3 that impacted credit markets negatively (CBK, 2015).

(World Bank, 2012) observed that coupled with its recent development of an attractive industry, Kenya has in the recent past maintained steady economic growth with a current GDP of 79.66 billion dollars, per capita of 1,796 dollars, and an average GDP growth rate of 4.8 per cent. Kenya is believed to have lost 1.51 billion dollars between 2002 and 2011 to trade misinvoicing. A recent study funded by the Danish government on its five priority countries (Ghana, Kenya, Mozambique, Tanzania and Uganda) shows that Kenya's tax loss from trade misinvoicing by multinational corporations and other parties could be as high as 8.3 per cent of government revenue, hampering economic growth and resulting in billions lost tax. A Banking Fraud Investigation Department report (CBK,2014) revealed that Kenyan Commercial banks lost more than Ksh 137 million to fraudsters in May alone 2014. The institutions targeted that month included First Community Bank, Barclays Bank of Kenya, Equity Bank, Paramount University Bank and Kenya Commercial Bank. Others are Cooperative Bank of Kenya, Commercial Bank of Africa, CFC Stannic, Habib Zurich Bank, National Bank of Kenya, Consolidated Bank and Family Bank (CBK, 2014).

The three motives for holding money include the transactions, precautionary and speculative motives. The transactions motive asserts that most transactions require money. Money passes from customers to firms to pay for the goods and services produced by firms; money passes from firms to employees to pay for the labor services supplied by workers to firms. Money balances that are held to finance such flows are called transactions balances. Total transactions balances vary with the value of the wage bill. If the wage doubles for any reason, the transactions balances held by firms and households for this purpose will also double, on average. As it is with wages, so it is with all other transactions: the size of the balances held is positively related to the value of the transactions (Lipsey and Chrystal 2014). (Ross, et al., 2009) documented that transactions- related needs come from normal disbursement and collection activities of the firm. The disbursement of cash includes the payment of wages and salaries, trade debts, taxes and dividends. Cash is collected from sales from operations, sales of assets and new financing. The cash inflows (collections) and outflows (disbursement) are not perfectly synchronized and some level of cash holdings is necessary to serve as a buffer. Another reason for holding cash is for compensating 
balances. Cash balances are kept at commercial banks to compensate for banking services rendered to the firm. MC Vaish, (2015) affirmed that the second motive of holding money is for precautionary purposes. Apart from demanding money for transactions motives, individuals and businessmen require money to meet unforeseen contingencies. One finds it convenient to hold some cash on which one can lean readily when some unforeseen need arises. (Joshi, 2011) confirmed that transaction motive takes care of normal routine functions but the business during its currency is engrossed with various contingencies and emergencies. It has to protect itself from such contingencies by holding additional cash in hand. This is known as precautionary motive. Such cash balance provides a cushion or buffer to meet unexpected demands. Some of the events warranting additional cash can arise owing to cancellation of an order, lock out, strikes, levy of duty or loss on raw material. The speculative motive relates to the holding of cash for investing in profit- making opportunities as and when they arise. The opportunity to make profit may arise when the security prices change. The firm will hold cash, when it is expected that interest rates will rise and security prices fall. Securities can be purchased when the interest rate is expected to fall. The firms also speculate on material prices. If it is expected that materials' prices will fall, the firm can postpone purchase and make purchases in future (Pandey, 2013). Karl et al. (2013) asserted that when interest rates are high, the opportunity cost of holding cash balance is high and there is a speculation motive for holding bonds in lieu of cash. You are speculating that interest rates will fall in the future and thus that bond prices will rise. Similarly, when market interest rates are lower than normal, you may expect them to rise in the future. Rising interest rates will bring about a decline in the price of existing bonds. When interest rates are low, not only are the opportunity cost of holding cash balances low, but, also there is a speculative motive for holding a larger amount of money.

Holt, et al (1999) explained that commercial Banks are the largest financial institutions and contribute immensely to economic growth. The main functions of Commercial Banks today are to lend money, accept deposits, and transfer money among businesses, other banks and financial institutions and individuals. The most common types of financial institutions include Commercial banks, Savings and loan associations, Mutual savings banks and Credit unions but Commercial banks make almost 40 percent of all mortgage loans and almost 50 percent of all other loans. Saleem (2013) documented that a commercial bank is a financial institution which deals with money and credit and is established to make profit. The main source of earnings of these banks is the interest charged on loans advanced to customers. A commercial bank accepts deposits from individuals, firms and companies and offers a certain interest and gives loans to those who need them at a higher interest rate. Gitman and Chad (2013) declared that commercial banks are among the most important financial institutions because they provide savers with a secure place to invest funds and they offer both individuals and companies loans to finance investments, such as the purchase of a new home and the expansion of a business. The traditional business model of commercial banks is taking in and paying interest on deposits and investing those funds back at higher interest rates- works to the extent that depositors believe that their investments are secure.

Benedikt at al, (2007) on cash management guidelines for commercial banks in U.S. observed that increases in cash financial strategies assist commercial banks to obtain mortgage stage. Ugraise, (2013) on the effect of cash control at the economic overall performance of commercial banks in Rwanda found out that cash control identity becomes determined to be important in ensuring profitability in Rwandan commercial banks. Cash management and cash planning were also established to be significant in organizational performance. Gaitho, (2010) conducted a survey of cash management practices with the aid of SACCOs in Nairobi. The findings revealed that majority of the SACCOs use cash planning practices to mitigate risks as a foundation for objective chance appraisal.

Muthama, (2016) on effects of cash management practices on operational performance of selected public hospitals in Kissi County, Kenya found out that cash budgets assist in making cash flow projections, ensures budgetary control, reduces initiative and innovation and controls a hospital's spending habits. However, the study realized that cash budgets may not interfere with the attainment of the hospital's goals and neither can it create competition of resources and policies. Ngumi, (2013) on the effect of bank innovations on financial performance of commercial banks in Kenya found out that bank innovations influence the financial performance of commercial banks. The adoption of innovations by commercial banks has a high potential of improving financial performance and hence better returns to the shareholders. The versatility of innovations has made their adoption rate to be high among both banks and their customers. Abdifatah, (2010) conducted a study on the link between liquidity threat and profitability of commercial banks in Kenya and found out that money collection of Kenyan commercial banks is affected negatively because of the liquidity gap and leverage.

Weda, (2015) carried out a study on influence of working capital management practices on financial performance of small and medium manufacturing enterprises in Nairobi county, Kenya found out that about 51.3 per cent often prepare cash budgets and preparing and reviewing cash budgets are frequently based on monthly periods. Ravi, (2012) did a study on the effect of credit risk control on commercial banks profitability in Nepal by way of studying the economic report of 31 commercial banks. The study findings revealed that money control, cash making plans and cash budgeting have a negative effect on banks' economic overall performance. However, the default price is the maximum financial indicator of economic performance. The study encouraged that the banks needed to design and formulate techniques to be able to best enhance publicity and profitability of 
commercial banks. A few of the studies carried out by various scholars on various areas do not address the subject of the determinants of Cash Flow Management on performance of Commercial Banks in Nairobi City County, Kenya. This study is therefore designed to fill this knowledge gap.

Banking Fraud Investigation Department report (CBK, 2014) reveals that there was rampant fraud of cash in commercial banks in Kenya in May 2014 alone thus affecting cash flow in these banks. This scenario precipitated this study to establish the actual situation on the ground. Cash flow problems can lead to business failure. When firms suffer from financial constraints, growth prospects are expected to cause increases in cash flow sensitivity and under investment. By contrast, as improving growth opportunities help to resolve over spending problems, cash flow sensitivity should decrease with growth Schoubben and Van Hulle, (2008). Even if the annual budget is balanced, with realistic revenue and expenditure estimates, in-year budget execution will not be smooth, since both the timing and seasonality of cash inflows and of expenditures can result in conditions of temporary cash surpluses or temporary cash shortfalls Lienert, (2013). Cash flow is crucial in the daily operation of a business. Liquidity in the business facilitates provision of working capital allowing the firm to source for inputs and pay its liabilities including its suppliers, staff and meet its tax obligations Schoubben and Van Hulle, (2008).

The major cause of liquidity risk is the maturity mismatch between assets and liabilities. The majority of the assets are funded by deposits most of which are current with a possibility to be called at any time. This situation is known as the mismatch between assets and liabilities. This is also called liquidity gap. Higher liquidity gap might create liquidity risk to most microfinance institutions in Kenya (CBK, 2013). Cash shortage is a chronic challenge to most firms, and yet cash management is very crucial to the survival and growth of commercial banks Attom, (2014). Lobel, (2013) found out that improper accounts preparation and inadequate cash management procedures are some of the major challenges facing organizations leading to close up of the enterprises. Schoubben and Van Hulle, (2008) documented that firms making profits and is unable to turn the debtors into liquid cash runs a risk of becoming insolvent despite having high sales. This is because inability to manage credit sales and hence cash flow will result in the firm being unable to meet its short term obligations. This will result in the firm running out of investment capital and being unable to attract creditors leading to reduced profits and shrinkage instead of growth.

The use of finance in Kenyan banking sector increased from 9.4 percent to 11.2 percent in 2009 and 2013 while ratios for obtaining credit were 3.3 and 4.2 respectively, an indication of increased activity according to (CBK, 2013). Banks need to safeguard gains made so far and build confidence since bankruptcy of Banks will be a manifestation of instability in the sector. Crisis such as the global financial markets faced since 2007 have grave implications for economic growth in developed and developing countries. Kenya's economy and financial system stability still face vulnerabilities with global risks. The global economic growth declined to 3.8 per cent in 2011 according to the FSR CBK, (2011).

Studies conducted on Cash Flow include Muthama, (2016) on the effects of cash flow management practices on operational performance of selected public hospitals in Kissi County and established that cash budgets assist in making cash flow projections, ensures budgetary controls, reduces initiative and innovation and controls a hospital's spending habits. Weda, (2015) conducted a study on influence of working capital management practices on financial performance of small and medium manufacturing enterprises in Nairobi county, Kenya found out that about 51.3 per cent often prepare cash budgets and preparing and reviewing cash budgets are frequently based on monthly periods, however, there is still an unexplored area in the cash flow management literature. This study seeks to bridge this knowledge gap by analyzing effect of cash forecasting practice on performance of commercial banks in Kenya.

\subsection{Liquidity Management Practice}

Nwaezeaku, (2008) defined liquidity as the degree of convertibility to cash or the ease with which any asset can be converted to cash sold at a fair market price. Don, (2009) Liquidity management is a concept that is receiving serious attention all over the world especially with the current financial situations and the state of the world economy. The concern of business owners and managers all over the world is to devise a strategy of managing their day to day operations in order to meet their obligations as they fall due and increase profitability and shareholder's wealth. CBK, (2012) documented that Liquidity management therefore involves the strategic supply or withdrawal from the market or circulation the amount of liquidity consistent with a desired level of short-term reserve money without distorting the profit making ability and operations of the bank. It relies on the daily assessment of the liquidity conditions in the banking system, so as to determine its liquidity needs and thus the volume of liquidity to allot or withdraw from the market. The liquidity needs of the banking system are usually defined by the sum of reserve requirements imposed on banks by a monetary authority.

Mwangi, (2014) found out that there is a significant negative relationship between liquidity risk management and financial performance of commercial banks. The results of the study show that a unit increase in liquid assets to total assets ratio decreases return on assets by $1 \%$. A unit increase in liquid assets to total deposits ratio decreases return on assets by $2.2 \%$. A unit increase in borrowings from banks decreases return on assets by $14.2 \%$. Finally 
the control variable which was asset quality shows that a unit increase in non-performing loans as a proportion of total loans would lead to a $12.4 \%$ decrease in return on assets. Karani, (2014) found out that liquidity is one of the determinants of profitability of commercial banks. The relationship between Return on Assets (ROA), Cash and cash equivalents, Capital ratio and Deposit ratio is positive implying that an increase in liquidity will lead to an increase in profitability of commercial banks. The study further revealed that for the success of operations and survival, commercial banks should not compromise efficient and effective liquidity management. They are expected to maintain optimal liquidity level in order to satisfy their financial obligations to customers or depositors and maximize profits for the shareholders. The optimal liquidity level is reached if the commercial banks religiously maintain the minimum liquidity requirement as stated by the Central Bank of Kenya. This attempt helps to reduce cases of bank distress. Both illiquidity and excess liquidity are financial Diseases that can easily erode the profit base of a bank as they affect bank's attempt to attain high profitability-level. The pursuit of high profit without consideration to the liquidity level can cause great illiquidity, which reduces the customers' patronage and loyalty. Therefore, any bank that has the aim of maximizing its profit level must adopt effective liquidity management. Effective liquidity management also requires adequate liquidity level which will help commercial banks to estimate the proportion of depositor's funds that will be demanded at any period and arrange on how to meet the demand.

Mogire (2003) studied working capital management among thirty public companies listed at the Nairobi Stock Exchange as at 31st December 2002. The objectives of the study were to determine the effects of profitability to companies, to investigate whether there is significant relationship between working capital management policy and the profitability of a company as measured by the return on equity and to establish if public companies in different sectors in Kenya follow different working capital management policies. Simple regression analysis was done to establish the relationship between working capital policy and return on equity. The results of the analysis showed that the commonly practiced working capital management policy among the public companies in Kenya is the aggressive approach policy and that there were no significant differences between the working capital management practices across the five sectors. Also there were no significant differences in return on equity among companies that practice different working capital management policies. The regression analysis also showed that the working capital management policy explained only fifty three percent of the variation in return on equity. Mureithi (2003) carried out an empirical investigation into the determinants of corporate cash holding for the Kenyan quoted companies. The study involved 29 companies quoted at the Nairobi Securities exchange (NSE) over a period of 10 years. The study used descriptive and quantitative statistics; he observed that one of the factors affecting corporate cash holding is the profitability of the entity. He observed that profitability conveys to the market credit worthiness and growth prospects of the firm. From the study there was positive relationship between profitability and liquidity. Kiprono (2004) studied the relationship between cash flows and earnings performance measures for companies listed in the NSE (Nairobi Stock Exchange). His objective was to determine the relationship between risk and return on assets (ROA), return on equity (ROE) and return on net assets (RONA) against the cash flows of firms. To achieve this, regression analysis was employed on thirty companies listed at the NSE. The companies were picked randomly and were analyzed for the five year period between 1998 and 2003. He concluded that there is a positive or direct association between cash flows from operating activities and all the return performance indicators. The results also showed that there is a negative relationship or indirect association between cash flows from financing and investing activities and returns performance indicators. Njihia (2005) found out that liquid assets significantly determine the profit of the commercial banks especially in the period after political instability after the elections. The ratio of deposits held, loans and advances held by the commercial banks influenced the profitability. Kamoyo (2006) carried out an empirical study on the determinants of liquidity of commercial banks in Kenya. The study involved 30 commercial banks operating in Kenya in the period 1995 to 2004. The study applied descriptive statistics, investigative questionnaires and multiple regression analysis to establish the determinants of liquidity in commercial banks. The results of the study indicated an insignificant negative relationship between profitability and liquidity.

Organizational performance is the measure of how efficient and effective an organization is- how well it achieves appropriate objectives (Stoner, et al, 2009). (Robbins and Coulter, 2013) affirmed that Organizational performance is the accumulated results of all the organization's work activities. (Cole, 2004) affirms that performance refers to how well an organization manages its resources effectively and efficiently to meet or achieve its goals. (Hornby, 2012) stated that performance is how well or badly something works. Performance of Commercial banks in Kenya can be measured using investing surplus cash, return on assets and return on equity (Ainsworth and Deines, 2009). Waweru (2009) affirmed that financial performance of a firm involves increased profitability, higher efficiency and increased output (Teruel, 2008). Assessment of managerial performance poses practical challenges. The capital market only has the current profit statement and other public disclosures with which to assess performance. These are inadequate measures of managerial quality since they ignore "soft issues" and strategic off-the balance sheet items in such as human resource development, expansion of production capacity and Research and Development whose return can only be realized in subsequent accounting periods (Star, 2008). 
The nature of a given financial performance indicator may be fundamental, as there is some disagreement regarding the extent to which any board or executive decisions might impact accounting versus market-based measures of financial performance. Besides, financial accounting returns are difficult to interpret especially in the case of multi- industry participation by firms. It is notable that financial accounting measures do not normally account for shareholder investment risk. Fearing the loss of their jobs, managers might put too much emphasis on how their decisions influence short-term profits and other public disclosures. Managers thus have a tendency to act myopically Mathuva, (2009). The emphasis on short-term performance is a common practice among executives. The danger is that current profits are over-valued by the market relative to strategic decisions that are likely to generate future profits. The danger is that current profits are over- valued by the market relative to strategic decisions that are likely to generate future profits. Hence, management will use a very high discount rate when making investment decisions. Good projects that reap their gains in the distant future will be ignored and bad projects with a short payback period accepted Michalski, (2009). Researchers have, however, relied on financial indicators of firm performance because they are readily available to the public. The typical financial indicators that have been commonly used are Return on Assets (ROA) and Return on Equity (ROE) Cohen, (2009: Meredith, 2010; McMahon, (2011). Researchers have, however, relied on financial indicators of firm performance because they are readily available to the public. The typical financial indicators that have been commonly used are Return on Assets (ROA) and Return on Equity (ROE) Cohen, (2009). Over-reliance on financial indicators to judge overall Commercial banks performance is often misleading especially if the Commercial bank in question has a lot of intangible assets component in its operations including human resources, Research and Development and other non-balance sheet assets. Hence, the need to pay attention to non-financial indicators of performance, or at least one that combines aspects of both, for a more comprehensive appraisal of firm performance cannot be overemphasized Emory, (2009).

Market-based returns have a number of advantages. They do reflect risk adjusted performance; they are not adversely affected by multi- industry or multinational issue may, however, be that market- based performance indicators are often subject to forces beyond management control Falope, (2009). As there appears to be no consensus regarding the efficacy of reliance on one set of indicators, a combination of financial and market -based indicators is recommended in order to capture the issues that are under the control of management as well as those that are market driven. This study will employ investing surplus cash, return on assets and return on equity to measure performance in Commercial banks in Kenya.

\subsection{Method}

The study used mixed research design which was both qualitative and quantitative studies were carried out at the same time and both were given equal weights. Creswell (2007) gives a broader definition of qualitative study as indicated by Denzin \& Lincoln, (2005) that qualitative research is a situated activity that locates the observer in the world. It consists of a set of interpretive, material practices that make the world visible. The target population of the study comprised of 6913 management and a supervisory cadre within commercial banks in Nairobi City County, Kenya which represented commercial banks in other counties. With a sample size of 346 through stratified sampling technique and a data collection instrument was questionnaire. Piloting was done to test the reliability and validity of the instrument. Data was analysed through SPSS package. Multiple regression analysis was done to test the significance levels of one variable over the other.

\subsection{Discussion}

Liquidity means the optimal level of cash and near cash assets held by the firm together with cash inflows and outflows of the firm Ekanem (2010). It is possible to measure a firm's liquidity with different types of cash flow ratios. These ratios are very helpful to determine the firm's financial health as well Jooste, (2006). One can measure the cash flow ratios on supplier and potential buyers in order to see if they are healthy and confirm that they do not have any liquidity problem Figlewicz \& Zeller, (1991). Nwaezeaku, (2008) defined liquidity as the degree of convertibility to cash or the ease with which any asset can be converted to cash sold at a fair market price. Ross et al.,(2009) explained that conceptually, cash management involves the determination of the optimal cash to hold by considering the trade- off between the opportunity cost of holding too much cash and the trading cost of holding too little. Cooley and Pullen, (2009) submitted that cash management is the process of planning and controlling cash flows. It consisted of three basic components: cash forecasting practices, cash surplus investment practices and cash-control practices. Atrill, (2010) affirmed that there is need for careful planning and monitoring of cash flows over time so as to determine the optimal cash to hold. Lienert (2009) found out that modern cash management has four major objectives, namely; to ensure that adequate cash is available to pay for expenditures when they are due, to borrow only when needed and to minimize government borrowing costs, to minimize returns on idle cash and to manage risks, by investing temporary surpluses productively, against adequate collateral. Lastly, the study sought to examine the effect of Liquidity management on performance of commercial banks in Nairobi County, Kenya. The findings are presented in a five point Likerts scale where $\mathrm{SA}=$ strongly agree, $\mathrm{A}=$ agree, $\mathrm{N}=\mathrm{neutral}$, 
$\mathrm{D}=$ disagree, $\mathrm{SD}=$ strongly disagree and $\mathrm{T}=$ total.

From table 4.1 the respondents were asked whether Liquidity management practice examines performance of commercial banks in Kenya. The distribution of findings showed that 58.2 percent of the respondents strongly agreed, 30 percent of them agreed, 10.9 percent of the respondents were neutral while 0.9 percent disagreed. None of the respondents strongly disagreed to the statement. These findings implied that majority of the respondents agreed that Liquidity management practice examines performance of commercial banks in Kenya. Karani, (2014) found out that liquidity is one of the determinants of profitability of commercial banks. The relationship between Return on Assets (ROA), Cash and cash equivalents, Capital ratio and Deposit ratio is positive implying that an increase in liquidity will lead to an increase in profitability of commercial banks.

The respondents were also asked whether Current ratio determines liquidity management practice in commercial banks in Kenya.The distribution of the responses indicated that 54.5 percent strongly agreed to the statement, 38.2 percent of them agreed and 6.4 percent of them were neutral while 0.9 percent of them disagreed. None of the respondents strongly disagreed to the statement. These findings implied that majority of the respondents agreed that Current ratio determines liquidity management practice in commercial banks in Kenya. Sardakis (2007), stated that to have efficient and effective liquidity management is very important for the survival of the firm. Pandey (2013) affirmed that current ratio is a measure of the firm's short term solvency. Indicates the availability of current assets to meet current liabilities. A ration of greater than one means that the firm has more current assets than current liabilities.

The respondents were further asked whether quick ratio determines liquidity management practice in commercial banks in Kenya. The distribution of the responses indicated that 58.2 percent strongly agreed to the statement, 30.9 percent of them agreed while 10.9 percent of them were neutral. None of the respondents disagreed or strongly disagreed to the statement. These findings implied that majority of the respondents agreed that quick ratio determines liquidity management practice in commercial banks in Kenya. Pandey (2013) affirmed that quick ratio, also called acid- test ratio, establishes a relationship between quick, or liquid, assets and current liabilities. An asset is liquid if it can be converted into cash immediately or reasonably soon without a loss of value.

The respondents were asked whether Cash ratio determines liquidity management practice in commercial banks in Kenya. The distribution of the responses indicated that 40.9 percent strongly agreed to the statement, 53.6 percent of them agreed while 5.5 percent of them were neutral. None of the respondents disagreed or strongly disagreed to the statement. These findings implied that majority of the respondents agreed that Cash ratio determines liquidity management practice in commercial banks in Kenya. Pandey (2013) documented that since cash is the most liquid asset, a financial analyst may examine cash ratio and its equivalent to current liabilities.

The respondents were further asked whether optimal liquidity level is reached if the commercial banks maintain the minimum liquidity requirement as stated by the Central Bank of Kenya.The distribution of the responses indicated that 35.5 percent strongly agreed to the statement, 50 percent of them agreed while 14.5 percent of them were neutral. None of the respondents disagreed or strongly disagreed to the statement. These findings implied that majority of the respondents agreed that optimal liquidity level is reached if the commercial banks maintain the minimum liquidity requirement as stated by the Central Bank of Kenya.

The respondents were also asked whether both illiquidity and excess liquidity are financial Diseases that can easily erode the profit base of a bank as they affect bank's attempt to attain high profitability-level. The distribution of the responses indicated that 42.7 percent strongly agreed to the statement, 44.5 percent of them agreed and 11.8 percent of them were neutral while 0.9 percent of them disagreed. None of the respondents strongly disagreed to the statement. These findings implied that majority of the respondents agreed that both illiquidity and excess liquidity are financial Diseases that can easily erode the profit base of a bank as they affect bank's attempt to attain high profitability-level. Finally, the respondents were asked whether the pursuit of high profit without consideration to the liquidity level can cause great illiquidity, which reduces the customers' patronage and loyalty. The distribution of the responses indicated that 42.7 percent strongly agreed to the statement, 44.5 percent of them agreed and 11.8 percent of them were neutral while 0.9 percent of them disagreed. None of the respondents strongly disagreed to the statement. These findings implied that majority of the respondents agreed that the pursuit of high profit without consideration to the liquidity level can cause great illiquidity, which reduces the customers' patronage and loyalty. 
Table 4.1: Effect of Liquidity management practice on performance of commercial banks in Kenya

\begin{tabular}{|c|c|c|c|c|c|c|c|}
\hline Statements & & SA & $\mathbf{A}$ & $\mathbf{N}$ & D & SD & $\mathbf{T}$ \\
\hline $\begin{array}{l}\text { Liquidity management practice examines performance of } \\
\text { commercial banks in Kenya }\end{array}$ & $\%$ & 58.2 & 30.0 & 10.9 & 0.9 & 0 & 100 \\
\hline $\begin{array}{l}\text { Current ratio determines liquidity management practice in } \\
\text { commercial banks in Kenya }\end{array}$ & $\%$ & 54.5 & 38.2 & 6.4 & 0 & 0 & 100 \\
\hline $\begin{array}{l}\text { Quick ratio determines liquidity management practice in } \\
\text { commercial banks in Kenya }\end{array}$ & $\%$ & 52.7 & 34.5 & 12.7 & 0 & 0 & 100 \\
\hline $\begin{array}{l}\text { Cash ratio determines liquidity management practice in } \\
\text { commercial banks in Kenya }\end{array}$ & $\%$ & 40.9 & 53.6 & 5.5 & 0 & 0 & 100 \\
\hline $\begin{array}{l}\text { Optimal liquidity level is reached if the commercial banks } \\
\text { maintain the minimum Liquidity requirement as stated by the } \\
\text { Central Bank of Kenya }\end{array}$ & $\%$ & 35.5 & 50.0 & 14.5 & 0 & 0 & 100 \\
\hline $\begin{array}{l}\text { Both illiquidity and excess liquidity are financial Diseases that } \\
\text { can easily erode the profit base of a bank as they affect bank's } \\
\text { attempt to attain high profitability-level }\end{array}$ & $\%$ & 42.7 & 44.5 & 11.8 & 0.9 & 0 & 100 \\
\hline $\begin{array}{l}\text { The pursuit of high profit without consideration to the liquidity } \\
\text { level can cause great illiquidity, which reduces the customers' } \\
\text { patronage and loyalty }\end{array}$ & $\%$ & 42.7 & 44.5 & 11.8 & 0.9 & 0 & 100 \\
\hline
\end{tabular}

\subsection{Inferential Statistics}

\subsubsection{Pearson Correlation}

The study sought to establish the strength of the relationship between independent and dependent variables of the study. Pearson correlation coefficient was computed at 95 percent confidence interval (error margin of 0.05). Table 4.2 illustrates the findings of the study.

Table 4.2: Correlation Matrix

\begin{tabular}{llr}
\hline Variances & & Performance of commercial banks \\
\hline \multirow{3}{*}{ Liquidity management practice } & Pearson Correlation & $.931^{* *}$ \\
& Sig. (2-tailed) & .000 \\
& N & 340 \\
\hline
\end{tabular}

As shown on Table 4.2 above, the p-value for liquidity management practice was found to be 0.000 which is less than the significant level of $0.05,(\mathrm{p}<0.05)$. The result indicated that Pearson Correlation coefficient ( $\mathrm{r}$-value) of 0.931 , which represented a strong, positive relationship between liquidity management practice and performance of commercial banks in Kenya.

\subsubsection{Multiple Linear Regression}

Multiple linear regressions were computed at 95 percent confidence interval ( 0.05 margin error) to show the multiple linear relationships between the independent and dependent variables of the study.

\subsubsection{Coefficient of Determination $\left(R^{2}\right)$}

Table 4.3 shows that the coefficient of correlation $(R)$ is positive 0.529 . This means that there is a positive correlation between effect of liquidity management practice and performance of commercial banks in Kenya. The coefficient of determination (R Square) indicates that $28.7 \%$ of performance of commercial banks in Kenya is influenced by the effect of liquidity management practice. The adjusted $\mathrm{R}^{2}$ however, indicates that $25.3 \%$ of performance of commercial banks in Kenya is influenced by the effect of liquidity management practice leaving $74.7 \%$ to be influenced by other factors that were not captured in this study.

Table 4.3: Model Summary

\begin{tabular}{lllll}
\hline Model & R & R Square & Adjusted R Square & Std. Error of the Estimate \\
\hline 1 & $.533^{\text {a }}$ & .287 & .253 & 9.20118 \\
\hline
\end{tabular}

a. Predictors: (Constant), liquidity management practice,

\subsubsection{Analysis of Variance}

Table 4.4 shows the Analysis of Variance (ANOVA). The p-value is 0.000 which is $<0.05$ indicates that the model is statistically significant in predicting how liquidity management practice affect performance of commercial banks in Kenya. The results also indicate that the independent variables are predictors of the dependent variable.

Table 4.4: ANOVA $^{\mathrm{a}}$

\begin{tabular}{lllllll}
\hline Model & & Sum of Squares & df & Mean Square & F & Sig. \\
\hline \multirow{4}{*}{1} & Regression & 686.766 & 5 & 192.603 & 48.172 & $.000^{\mathrm{b}}$ \\
& Residual & 1891.232 & 335 & 17.965 & & \\
& Total & 2840.000 & 340 & & & \\
\hline
\end{tabular}




\subsubsection{Regression Coefficients}

From the Coefficients table (Table 4.5) the regression model can be derived as follows:

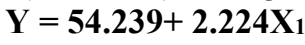

The results in table 4.5 indicate that all the independent variables have a significant positive effect on performance of Commercial banks in Kenya. The most influential variable is liquidity management with a regression coefficient of 2.224 ( $p$-value $=0.000)$. According to this model when all the independent variables values are zero, performance of Commercial banks in Kenya will have a score of 45.743.

\begin{tabular}{llllll}
\multicolumn{1}{l}{ Table 4.5: Regression Coefficients } & & & \\
\hline Model & Unstandardized Coefficients & $\begin{array}{l}\text { Standardized } \\
\text { Coefficients } \\
\text { Beta }\end{array}$ & T & Sig. \\
& B & Std. Error & & 54.239 & .000 \\
\hline 1 (Constant) & 45.743 & 2.638 & & 6.514 & .000 \\
\hline $\begin{array}{l}\text { Liquidity } \\
\text { management } \\
\text { practice }\end{array}$ & 2.224 & .181 & .803 & &
\end{tabular}

\subsubsection{Hypotheses Testing}

Ho1: Liquidity management does not have a significant effect on performance of Commercial banks in Kenya. From Table 4.5 above, liquidity management practice $(\beta=2.224)$ was found to be positively related to performance of Commercial banks in Kenya. From t-test analysis, the $t$-value was found to be 6.514 and the $\rho$-value 0.000 . Statistically, this null hypothesis was rejected because $\rho<0.05$. Thus, the study accepted the alternative hypothesis and it concluded that liquidity management practice affects performance of Commercial banks in Kenya.

\subsection{Conclusion and Recommendation}

In conclusion, basing on the findings, liquidity management practice $(\beta=2.224)$ was found to be positively related to performance of Commercial banks in Kenya. From t-test analysis, the t-value was found to be 6.514 and the $\rho$ -value 0.000. Statistically, this null hypothesis was rejected because $\rho<0.05$. Thus, the study accepted the alternative hypothesis and it concluded that liquidity management practice affects performance of Commercial banks in Kenya. The study recommends that the management of commercial banks in Kenya should be enhanced through frequent audits to be able to curb interest rates especially the unanticipated inflation which adversely affects the functions of money by undermining wealth holders' confidence in its ability to be used as medium of exchange and store of value. The firms should have plans for their cash needs and requirements during a projected period, particularly one year and above to enable them achieve their set goals in advance and reduce the cost of capital and increase the returns of excess cash. They should also make sure that the company's cash funds are in the optimal utilization and there are no extra borrowings. They should also focus on surplus funds to invest in market securities and that that period of inflation; lenders lose while borrowers gain because the real value of the debt declines. They should also carry out cash accounting practice to evaluate cash performance in these commercial banks. Commercial banks within the country should manage their cash receivables to enhance organisational performance. The government should manage creditor's turnover and payables deferral period to determine payables management to enhance performance of commercial banks. They should also maintain the minimum liquidity requirement as stated by the Central Bank of Kenya as both illiquidity and excess liquidity are financial diseases that can easily erode the profit base of a bank as they affect bank's attempt to attain high profitability-level. They should also put into consideration liquidity levels in pursuit of high profit for it can cause great illiquidity, which reduces the customers' patronage and loyalty.

\section{References}

Abdifatah, L.M. (2010). The impact of Cash Management on Cash holding: A Quantitative Study of Swedish Manufacturing SMEs, Mid Sweden University, and Faculty of Human Sciences and Department of Social Sciences.

Abdul-Rahamon, O.A. \& Adejare, A.T. (2014). The Analysis of the impact of Accounting Records keeping on the Performance of the Small Scale Enterprises. International Journal of Academic Research in Business and Social Sciences, 4(1), 1-17.

Abioro, M. (2013). The impact of cash management on the performance of Manufacturing companies in Nigeria. Uncertain Supply Chain Management, (1),177-192.

Ademola, G. O., Samuel O. J. \& Ifedolapo, O. (2012). The Roles of Record Keeping In The Survival and Growth of Small Scale Enterprises in Ijumu Local Government Area of Kogi State. Global Journal of Management and Business Research,12(13), 54-66

Ainsworth, P. \& Deines, D. (2009). Introduction to Accounting: An Integrated Approach. $5^{\text {th }}$ ed. New York: McGraw-Hill.

Aikaeli, J., Mugizi, F. and Ndanshau, A. (2011). The Determinants of Interest Rate Spreads in Developing 
Countries: Evidence on Tanzania, 1991-, (Working Paper No. 02/11.2009). Dar es Salaam, University of Dar es Salaam, Department of Economics.

Akunga, G. (2013). The Regional programme of Enterprise Development Survey,993[16]95: Structure and performance of Manufacturing in Kenya. London: Palgrave.

Amin, M.A. (2004). Foundation of Statistical Inference for Social Science Research. Kampala: Makerere University Printery.

Atieno, R. (2009). Linkages, access to finance and the performance of small-scale Enterprises in Kenya. Journal of Accounting and Business Research, 3(1), 33-48.

Attom, E.B. (2014) .Cash Management Practices by Micro and Small-Scale Enterprises At Kasoa in the Central Region of Ghana. Asian Journal of Business andManagement Sciences, 3(2), 1-12.

Atrill, P. (2008). Financial Management For Decision Makers (4th ed). Sydney: Longman Professional.

Back, D. (2009).Success in Small Business: the Role of the Financial Adviser Sydney: Longman professional.

Baker W. E. (1986). Agency costs of free cash flow corporate finance, and takeovers. The American Economic Review, 76(2), 323-329.

Barr, A. (2009). The functional diversity and spillover effects of social capital of African Economies, Journal of Accounting and Business Research 11(1), 14-29

Barrow, C. (2010). Financial Management for the Small Business: The Daily Telegraph guide, (2nd ed), London: Kogan Page,

Beaver, W. (2009). Financial reporting, supplemental disclosures, and bank share prices. Journal of Accounting Research, 27(2), 157-178.

Benedikt, Simon and Daniel. (2007). Customer satisfaction, market share and profitability: findings From Chastain Christopherson (2008) From Risk Taker Manager: Ten Principles for Establishing a comprehensive Risk Management System for Banks.

Beardshaw, J., D. Brewster, P. Cormack and A. Ross. (2001). Economics: A Student's Guide. $5^{\text {th }}$ ed. New York: Prentice Hill.

Bodgam R. and S. Bilken.(1992). Qualitatve Research for Education. Boston: Allyn and Bacon.

Blocks, S. and Hirt, G. (2009). Foundations of Financial Management. London: Irwin

Brealey, Myers, Marcus. (2009). Fundamentals of Corporate Finance. 6th ed. New York: McGraw Hill.

Brigham, E. F. and Ehrardt, M. C. (2005). Financial Management: Theory and Practice. 10th Ed. International Student Edition, San Diego: Harcourt Publishers.

Brigham, E. F. and Daves, P. R. (2007). Intermediate Financial Management. London:

Library of Congress.

Brigham, E.F. and Houston, J.F. (2012). Fundamentals of Financial Management. New Delhi: Cengage Learning India Private Ltd.

Chamberlin, G. and Linda, Y. (2011). Macroeconomics. London: Library of Congress.

Cole, G. (2004) .Management Theory and Practice. $6^{\text {th }}$ ed. London: Library of Congress.

Cooley, P. \& Pullen, R. (2009). Small business cash management practices, American Journal of Small Business, $4(2), 1-11$.

Cooper, R. and Pamela, S. (2010). Business Research Methods. $9^{\text {th }}$ ed. New York: McGraw-Hill.

Creswell, J. W. (2003). Research Design: Qualitative, Quantitative and Mixed Methods and Approaches (2nd ed.). Thousand Oaks, CA: Sage.

Cropper, L., P. Rising and A. Fison. (1958). Book keeping and Accounts: A text of Accounts: London: Richard Clay and Company Ltd.

Dechow, P. M. (1994). Accounting earnings and cash flows as measures of firm Performance: The role of accounting accruals. Journal of accounting and Economics, 18(1), 3-42.

Donnelly. (2015) .Illicit Financial Flows Costing Africa Billions. Addis Ababa: Africa Development Bank.

Folawewo A. and Tennant D. (2008). Determinants of Interest Rate Spreads in Sub-Saharan African Countries: a Dynamic Panel Analysis. Paper prepared for the 13th Annual African Econometrics Society Conference, 9 11 July, 2008, Pretoria, Republic of South Africa.

Garrison, H. and Noreen, W. (2002). Managerial Accounting. $9^{\text {th }}$ ed. Boston: Irwin/McGraw-Hill.

Ghosh, N. B. (1999) .Scientific and Research Method. $4^{\text {th }}$ ed. New Delhi: Sterling Publisher.

Gitman, L. and Chad, Z. (2013) .Principles of Managerial Finance. London: Pearson Educational Publishers.

Gitman, L.J. (2008). Principles of Managerial Finance. $11^{\text {th }}$ ed. New Delhi: Pearson Education Publishers.

Glautier, et al. (2011) .Financial Accounting. New York: McGraw-Hill.

Grant, S. and Stanlake, G. (2011). Introductory Economics. $7^{\text {th }}$ ed. London: Pearson Education Publishers.

Griffin, W. R. (2002). Management. $7^{\text {th }}$ ed. Boston: Houghton Mifflin Company.

Hardwick, Philip, Khan, Bahadur, Langmead and John. (1999). An Introduction to Modern Economics. $5^{\text {th }}$ ed. New York: McGraw-Hill.

Haven, J. (2008). The Financial Crisis of 2008: Year in Review 2008. Washington DC. Britannica Publishers 
Hilton, R., M. Mahar and F. Selto. (2003). Cost Management: Strategies for Business Decisions. 2nd ed. Boston: McGraw-Hill Irwin.

Hillier, Ross, Westerfield, Jaffe and Jordan. (2013). Corporate Finance. $2^{\text {nd }}$ ed. London: McGraw-Hill.

Higgins, C. R. (2004). Analysis for Financial Management. Boston: McGraw -Hill Company .

Hornby, A. S. (2012). Oxford Advanced Learner's Dictionary. $8^{\text {th }}$ ed. London: Oxford

University Press.

Holt, Rinehart, and Winston. (1999). Economics. New York: Harcourt Brace Company.

Horngren, C. T. and Foster, G. (2013) Cost Accounting: A Managerial Emphasis. $11^{\text {th }}$ ed. New Delhi: Prentice Hall of India Private Limited.

Horne, V. J et al. (2008). Fundamentals of Financial Management. 12 ${ }^{\text {th }}$ ed. London: Prentice- Hall.

Horne, J. and James, C. (2009) Financial Management and Policy. 12th ed. London: Prentice- Hall.

Horne, V.J. and Wachowictz, J.M. (2009). Fundamentals of Financial Management.13 ${ }^{\text {th }}$ ed. New Delhi: Asoke Publishers.

Hussey, L. and Hussey, R. R. (1997). Business Research: A Practical Guide for Undergraduate and Post Graduate Students. London: Macmillan Publishers.

Hussain, A. (1996). Business Finance. Nairobi: Kijabe Printing Press.

Jensen, M. C. (1986). Agency costs of free cash flow, corporate finance, and takeovers. The American Economic Review, 76(2), 323-329.

Joshi, R.N. (2011). Cash Management: Perspectives, Principles and Practices. New Delhi: New Age International Publishers.

Kakoza, T. (199). An Introduction to Research Methodology. Kampala: The National Adult Education Association.

Kapoor, L., R. Dlabay and J.H.Robert . (2001). Personal Finance. New York: McGraw-Hill.

Khawaja, I. and Musleh, Ding. (2007). Determinants of Interest Spread in Pakistan.Working Papers 2007:22). The Pakistan Development Review, Pakistan. Islamabad.

Khan, M, Y. and Jain P, K. (2001). Management Accounting. 3rd ed. New Delhi:McGraw - Hill Publishing Company Limited.

Kithinji, M. and Waweru, M. (2007). Merger Restructuring and Financial Performance of Commercial Banks in Kenya. Journal of Economics, Management and Financial Markets, 2, (4).

Karl, E., R. Fair and S. Oster. (2013). Principles of Economics. 10th ed. New York: British Library.

Kothari, R, C. (2004). Research Methodology: Methods and Techniques. $2^{\text {nd }}$ ed, New Delhi; New Age International Publishers.

Kwame, K. (2008). Working capital management practices of small firms in the Ashanti Region of Ghana. Journal of Business Finance Account, 3(1-4), 1-4.

Lazaridis, I. \& Tryfonidis, D. (2006). "Relationship between Working Capital Management and Profitability of Listed Companies in the Athens Stock Exchange", Journal of Financial Management and Analysis, 19(1), 26-35.

Lerner, J.J. and Gokarn, R.Y. (2007). Bookkeeping and Accounting. $4^{\text {th }} \mathrm{e}$. New York: McGraw-Hill.

Lienert, I. (2009). Modernizing Cash Management. Fiscal Affairs .Washington D.C:World Bank; International Monetary Fund.

Lipsey, R. and Chrystal, A. (2014). Economics. 12 $2^{\text {th }}$ ed. New York: Oxford University Press.

Lumbay, S. And Jones, C. (2011). Corporate Finance. Theory and Practice, London: Library of Congress.

Manasseh, P. (2010) .A Text Book of Financial Management. Nairobi: Kijabe Printing Press.

Mesia, G. W. and Balken, B. D. (2002). Management. Boston: McGraw-Hill.

McLaney, E. (2011). Business Finance; Theory and Practice. $9^{\text {th }}$ ed. London Prentice Hall.

Moyer, R.C, Maguigan, J.R. \&Kretlow, W.J. (2001). Contemporary Financial Management. Ohio: South Western Publishing.

Moomaw and Olson (2007). Economics and Contemporary Issues. $7^{\text {th }}$ ed. New York: Library of Congress.

Mudida, R. (2014). Modern Economics. $2^{\text {nd }}$ ed. Nairobi: Focus Publisher.

Mugenda, G. and Mugenda, O. (2011) .Research Methods: Quantitative and Qualitative Approach. Nairobi: Acts Press.

Mungai, A. (2014). The impact of cash management on profitability and sustainabilityOf small retail businesses in the Tongaat area, KwaZulu-Natal. Published MasterOf Technology Report, Durban University of Technology, South Africa.

Muranaga, J. \& Ohsawa, M. (2002). Measurement of liquidity risk in the context of Market risk calculation, working paper, Institute for Monetary and Economic Studies, Bank of Japan, Tokyo.

Namusonge, G. and Anyangu, M. (2011). Business Finance: Principles and Practice. Beau Bassin: VDM Publishing House Ltd.

Namusonge, G. (2010). Business Statistics: Concepts and Application. Saarbrucken: VDM Publishing House.

Ngugi, R. (1999). “An Empirical Analysis of Interest Rate Spread in Kenya.” AERCResearch Paper. Nairobi, 
AERC.

Ngugi, R. (2001). An Empirical Analysis of Interest Rate Spread in Kenya. African Economic Research Consortium Research Paper 106, Nairobi, AERC.

Nguyen, K.M. (2001). Financial management and profitability of small and medium Enterprises. DBA thesis, Southern Cross University, Lismore, NSW.

Nzomo, D.N. (2002). Basic Accounting: Fundamentals, Principles, and Procedures. Nairobi: University of Nairobi Press.

Okwena, K.D., Okioma, T. \& Onsongo, E.N. (2011). An assessment of the effect ofProper book keeping practices on the financial performance perspectives fromSmall and medium scale business enterprises in Kisii municipality. WorkingPaper, Kisii University College, Kenya.

Owler, L. W. J. and Brown, J. L. (2009). Weldon's costing. Hong Kong: Long Man (Fe) Ltd.

Pandey, I. M. (2013). Financial Management.11 $1^{\text {th }}$ ed. New Delhi: Vikas Publishing House Pvt Ltd.

Rahaman, A.S. (2010). Public Sector Accounting and Financial Management in a Developing Country Organizational Context: A Three-Dimensional View: Armidale, University of New England, 1; 121-153.

Ravi, P. \& Sharma, P. (2012).The impact of credit risk management on financial Performance of commercial banks in Nepal, International Journal of Arts and Commerce, University of New England Australia.

Ravi B. (2012). The impact of credit risk management on financial performance of Commercial banks in Nepal. International journal of Arts and commerce, 1 (5) RIA Group, New York.

Robbins, P. and Coulter, M. (2013). Management: Horizon Edition. Boston: PearsonPublishers.

Ross, S, A. (1999) Corporate Finance. New York: McGraw-Hill.

Ross, S. A., Westerfield, W. W. and J. Jaffrey. (2008). Corporate Finance. $9^{\text {th }}$ ed. New York: McGraw- Hill.

Ross, S. A. and Randolph, W. W. (2010). Fundamentals of Corporate Finance. $9^{\text {th }}$ ed. Boston: McGraw- Hill.

Saleem, N. A. (2013). Cost Accounting Simplified. Nairobi: Saleem Publishers.

Saleem, N. A. (2013). Economics Simplified. Nairobi: Saleem Publishers.

Samuelson, P.A. and Nordhaus, W.D. (2008). Economics. $12^{\text {th }}$ ed. New York: McGraw-Hill.

Schall, L. and Haley, C. (2008). Introduction to Financial Management. New York: McGraw-Hill.

Schoubben, F., \& Van Hulle, C. (2008). The Impact of a Stock Listing on The Relationship between Growth Opportunities and Investment-Cash Flow Sensitivity. Katholieke Universiteit.

Vaish, M. C. (2015) .Economic Theory. $14^{\text {th }}$ ed. New Delhi: Vikas Publishing House.

Ward, T. B. (1994). Cognition, creativity, and entrepreneurship. Journal of business venturing,19(2), 173-188.

Warren, Reeve and Duchac. (2007). Financial Accounting. London: Library of Congress.

Waweru, K. (2009). Determining cash balance management practices: The Journal of Applied Finance, 15(8), 10 20.

Wesonga, M. J .W. (2012) .Economics: Text Book. Nairobi: Kenya Literature Bureau.

Williams, et al.(2008).Financial and Managerial Accounting, McGraw-Hill Irwin- New York.

Williams, et al. (1998). Financial and Managerial Accounting: The Basis for Decisions. $12^{\text {th }}$ ed. Boston: McGrawHill.

Wild, J.J., K.D. Larson and B. Chiappetta. (2007) .Fundamental Accounting Principles. $18^{\text {th }}$ ed. New York: McGraw-Hill.

Wood, F. and Allan, S. (2012). Business Accounting. 12 $2^{\text {th }}$ ed. London: Pearson Publishing House.

Zikmund, G., Babin, J., Carr, J. and Griffin, M. (2010). Business Research Methods 8th Edition, South-Western, Cengage Learning. 